(52); Clay-colored Sparrow 100 (118) ; Harris' Sparrow 67 (108); White-crowned Sparrow 81 (93); White-throated Sparrow 184 (90); Fox Sparrow 2 (2) ; Lincoln's Sparrow 74 (18) ; Song Sparrow 12 (10); McCown's Longspur 4 (82) ; Lapland Longspur 7816 (1252); Chestnutcollared Longspur 886 (124); Snow Bunting 1 (1).

Total Species, 134. Individuals 17,634. Participants: Jack Bailey, Jessie Bailey, Al Binnie, Betty Binnie, Greg
Bobbitt, Bill Brownlee, Frances Churchill, Nancy Coppin, Lynne Cross, Iola Crouse, George Dodd, Lucy Eley, Elmer Fox, Pearl Guest, Florence Hailstone, Bernie Haysom, Keith Haysom, Linda Hebert, Mrs. M. Horn, Gwen Jones, Harold Jowsey, Harriet Jowsey, Jim Jowsey, Shirley Jowsey, Helen Keay, Ferne Lawrence, Betty MacGregor, Colin McConnell, Helen Morrison, Joan Powell, Connie Pratt, Joe Roberts, Mrs. G. Smith, Mrs. Sykes, Charles Thacker, Dan Walker. Compiled by $A l$ and Betty Binnie.

\title{
BLACK-CHINNED HUMMINGBIRD REPORTED AT REGINA
}

\section{by Shirley Jowsey and J. R. Jowsey, 2635 19th Ave., Regina}

Hummingbird arrivals before June 1 are not unusual here in Kegina, but the sight of a hummingbird resting on a branch of our crabapple tree at noon on June 1,1970 was unusual enough to alert us to examine the bird closely. The bird was sitting in a position where we could observe it through the window of the house without alarming it, even though it was only seven feet from us. As it turned to face us, we noticed the absence of the bright ruby throat patch which we had expected to see, since the Rubythroated Hummingbird is the species likely to be observed in Regina.

Subsequent examinations of this bird on its return visits to the crabapple tree that day allowed us to observe all the field marks of the male Blackchinned Hummingbird. The main throat patch was distinctly black, as observed in several types of lighting, and the violet area below the black throat patch was clearly seen on two occasions.

In addition to the male hummingbird described above, we observed a female hummingbird several times on the evening of June 1. Since females of Blackchinned and Ruby-throated hummingbirds are similar in plumage patterns, we cannot be certain that the female was also a Black-chinned Hummingbird.

Unfortunately, we were not able to show the bird to another observer that day to get a verification of our identification, and no sightings of the pair were made on the following day. The Black-chinned Hummingbird is not on the provincial checking-list for Saskatchewan, and, to the best of our knowledge, it has not previously been reported in the province. W. Earl Godfrey in The Birds of Canada (1966) describes its status in Canada as that of a "scarce summer visitant, probably breeding, in southern interior British Columbia (Chilliwack east to Creston, north to Grindrod)." Its distribution is more general to the south of the border, and the A.O.U. Check-List (1957) gives it as breeding "from southwestern British Columbia and northwestern Montana (Columbia Falls) south through western Montana, central Idaho, western Colorado, New Mexico, and south-central and southwestern Texas... to northern Baja, California . . . Sonora, and extreme southwestern Chihuahua." No records of its occurrence in Alberta are cited in Salt and Wilks, The Birds of Alberta (rev. ed., 1966).

Local weather conditions did not suggest a reason for the sighting of this rare bird in Regina, but larger weather disturbances may have pressed a pair eastward from their normal migration route to Montana and southern British Columbia. 